\title{
The Khom script of the Kommodam Rebellion
}

\author{
PAUL SIDWELL
}

\section{Abstract}

This article describes a previously undescribed script from Laos. The script was used by a political leader as part of his resistance effort against the colonial French, used to symbolize his power more than to communicate factual content. The script is unique in the way it has separate symbols for syllable onsets and codas.

\section{Introduction}

I was privileged to be introduced to a mysterious indigenous script during field work on the Boloven Plateau (Champasak Province, Lao PDR) in 1998, a script which, to my knowledge, is undescribed in published linguistic literature. ${ }^{1}$ The so-called "Khom script" was reportedly devised and used by Ong Kommadam (also romanized as Khomadam, Kommadan), ${ }^{2}$ leader of the anti-French rebellion on the Bolovens from 1901 to 1936 . The script is unprecedented in its formal characteristics and is also noteworthy for having more than 300 characters, some clearly inspired by various Southeast Asian scripts, others pure invention. The inventory of characters is apparently extensive enough that it can be used to write any language of the area, although the extent that it was really used is unknown.

Besides the interesting formal characteristics of the script, which we can describe and analyze, there remain mysteries that may never be solved. Principally are the questions of why the script came into being in the first place, and then so suddenly and completely vanished from view. Today's older Loven nostalgically remember that they had their own writing during the time they asserted their independence. However, it is only the fact of the script that is remembered, the form is not, as no tradition of writing in it survived beyond the end of the rebellion in 1936. In this article, in addition to presenting a description of the writing system, I will suggest 
that its primary function, at least by default if not by intent, was symbolic. As a language-planning tool it died with the revolt - the Kommadam family and supporters subsequently threw their support behind the nationalist Pathet Lao movement, ultimately committing the "Khom" to assimilate culturally and linguistically to mainstream Lao society, a process now in full swing.

\section{The Kommadam Rebellion}

The following summary of historical events, given to help readers understand the historical setting for the origin and use of the Khom script, is based on the texts of Murdoch (1974), Moppert (1981), and Gunn (1990). In 1893, France formally took possession by treaty of Siamese territories east of the Mekong, effectively creating a new country out of several semi-autonomous tribute states. French rule was not kind to the citizens of her new protectorate, particularly to the $\mathrm{Kha}^{3}$ - the many ethnically Mon-Khmer communities that constituted perhaps half the population. A burdensome poll tax regime was imposed that permitted no exceptions for poverty, with corvée labor required in lieu of monetary payment, and often arbitrarily imposed to satisfy the needs of public works. Submission to France thus cost the Kha the semi-autonomy they had enjoyed under the more inefficient and informal traditional Siamese/ Lao administration. That autonomy was not only essential to Kha identity and village economy, it had minimized the humiliations of dealing with the Lao Loum (lowland Lao), who looked down on them as something less than human. ${ }^{4}$

Resistance to the emerging order rose swiftly among the Kha, realized in the south of Laos with the so-called "Holy Man's Rebellion" led by the messianic Bac My (also called Ong Keo), of the Alak tribe. Bac My's rebels caused considerable damage and embarrassment to the French who, in no position to attack their hideouts on the Boloven Plateau, instead took on his popular support base, and over 1901-1902 killed probably a third of the civilian population of the plateau. The rebellion continued in fits and starts over the first decade of the twentieth century, with armed bands forming and reforming under the leadership of various of Bac My's inner circle, including Ong Kommadam (claimed by the Kha Loven as one of their own, although identified as Nyaheun by Gunn [1990: 114]).

Bac My surrendered in 1905 and, after swearing loyalty to the regime, enjoyed a fairly liberal house arrest, which allowed him to continue to conduct religious ceremonies. In 1909 the locals held a great festival for Bac My, who traveled from village to village receiving offerings. The 
French Résident Supérieur of Salavan, Jacque Dauplay, invited Bac My into his home in order to view some photographs and brazenly had him bayoneted to death. Dauplay was later exonerated of this outrage by the colonial authorities, and rewarded with promotion and transfer to a post in northern Laos.

In November 1910, Kommadam invited Dauplay for negotiations at his base at Phou Luang (the "Big Mountain" ridge at the northeast of the Boloven Plateau), only to have Dauplay pull a pistol from his pith helmet and shoot him twice in the chest within minutes of entering the room. Although initially satisfied that the shots were fatal, Dauplay was mistaken, and Kommadam escaped to recover full health. The story of his miraculous strength spread among the plateau dwellers, who took it as proof of his self-proclaimed supernatural status.

Over the next 26 years, Kommadam led the most successful sustained resistance to French rule in Indo-China before World War II. In 1924 he began distributing propaganda, some of it in his newly devised Khom script, as far as Cambodia and Annam, and in 1926 declared himself variously "King of the Khom," "God of the Khom," "Sky God of the Khom" (see discussion of Figure 4). As ruler, he asserted the right to collect taxes at his discretion and launched a campaign against corvée labor.

Official colonial tax collections from Boloven villages declined as more and more Loven and Nyaheun gave their loyalty to the "the master who exercises no corvées" (Moppert 1981: 55). In the 1930s, Kommadam pursued an increasingly religious agenda, staging larger and larger boun ceremonies at Ban Thong Vay, where village heads and other dignitaries came to pay their respects to the self-styled incarnation of the Buddha.

At the beginning of 1936, the colonial authorities launched a massive assault on the plateau and upper Sekong valley, including bombardment from aircraft and the use of elephants to trample villages and crops. In January, Kommadam was killed and eventually hundreds of his followers where killed. By April, survivors in chains were back to work on corvée. Thus it had taken more than 40 years for French rule to be imposed over the south of Laos, a mere 13 years before self-rule would be granted in 1949 .

\section{The Khom script}

In 1998, I was taken to meet an 84-year-old Alak man, Mr. Boun Nyong, who was living in a small Loven village about 20 kilometers north of Paksong. There, over approximately two hours, Boun Nyong wrote out and pronounced the characters of the script. He explained that at the age of 
20 (so apparently in about 1934) he was recruited to learn the script, so to serve as secretary to Kommadam, and spent two years becoming proficient in its use. With the defeat of the rebels in 1936 it all came to an end, and only he and one other man (unnamed), who allegedly had the characters tattooed on his back, survived with a knowledge of the writing system.

Two weeks later, I returned to Paksong from a trip to Vientiane to renew my visa, only to be told that I had missed Boun Nyong's funeral by two days. It was a great shock to realize that he had chosen me, a complete stranger, to unburden himself upon before passing away. About a week later I was told that a niece of the Kommadam still lived in Paksong and held several notebooks in which the script was written. After making some enquiries I eventually tracked down the niece, and she generously allowed me to copy the contents of two small exercise books that contained some lists of words, such as numerals and days of the week in the Loven language written in the script. These records proved to be invaluable in terms of explaining (or at least allowing me to work out) how the system rendered the sounds of Loven, since Boun Nyong had (it turned out) given me Lao phonetic readings of the characters; that is, readings that conflated sounds that are distinct in Loven but merged in Lao.

My subsequent analysis reveals the script to be a marvel of invention and sophistication. Quite unlike any other script of the region, it is neither phonemic, alpha-syllabic, nor hieroglyphic - instead it uses two distinct series of characters to encode the onsets and rhymes of each syllable, hence it may be categorized as an "onset-rhyme" script. It was my first theory that the script had been devised by a linguistic genius to exactly deal with the phonology of Loven, but that idea was too bold. I have since been passed a letter from John Davis of Colorado, written in 2007 (via Peter Unseth). Davis had worked as a missionary in Laos in the late 1960s and had a similar interview (as I had had 30 years later) with an aged former Kommadam confidante in 1967 or 1968. Davis reports that Kommadam consciously modeled his script on Chinese, which he mistakenly believed required words to be written with two characters each. Presumably supposing Chinese to be phonetic rather than logographic, he settled upon dividing words into onsets and rhymes, and thus set about creating sufficient characters of this nature to represent the requisite sounds.

The reported method by which the characters were created is the stuff of magic itself. Davis' letter summarized the scribe's description of it:

[...] Komandame [sic] would go into a trance (a possible demonic possession), he would repeat the sound over and over again, as the symbol appeared on the naked flesh of his chest. Once the scribe had recorded it, there would be another. After 
these sessions, Komandame would be utterly exhausted, and sometimes sleep for the next day.

However the actual method of creation, the ultimate set of characters reflects more or less the full set of possible onsets and rhymes in not only Loven but all the various other languages of the region, including Lao, of which we have some examples, although without perfectly representing tones. $^{5}$

Presently my analysis of the script has not progressed beyond the limited scope made possible by the data I obtained from the interviews and notebooks mentioned above. This consists of 250 rhyme characters and 64 initials with tentative phonetic assignments, and 148 unidentified characters. These are given in Figures 1-3. However, more data has come into my hands that should allow me to advance the analysis considerably in due course.

As reported by Gunn (1990: 118-120), Kommadam sent to the Résident Supérieur a letter dated 22 February 1926, written in Lao, stating his grievances and offering terms for peace. No response was made, so one year later another copy was made and this was sent to Prince Phetsarath, head of the Lao Civil Service. The prince translated the letter into French, and parts of it were further translated into English in Gunn's book. In 2000, Michel Ferlus (CNRS Paris) sent me photocopies of four papers, at least one of which is the 22 February 1926 letter written in the cursive Lao style of the time. The other three are of similar length but are written in Khom script. I believe that one of these is the 22 February letter in Lao but transliterated into Khom script. My preliminary examination of the text shows that various of the so far unassigned characters are present, so my expectation is that a careful syllable-by-syllable comparison should extend the analysis significantly.

Use of Khom script is illustrated in Figure 4, in which one can see a fragment of the Lao language version of the letter, bearing Kommadam's seal and two "signatures" in the Khom script. The two "signatures" transcribe phonetically as [pha?cawkhoom] and [cawfaakhoom], and are thus the Lao appellations "God of the Khom" and "Sky God of the Khom." Figures 1-3 lay out the characters of the script according to my analysis in progress.

\section{What was the function of the script?}

Many older Loven people I have interviewed proudly recall that the Kommadam gave them a script for their language, like a "real" nation. 


\begin{tabular}{|c|c|c|c|c|c|c|c|c|}
\hline & $-p$ & $-\mathrm{m}$ & $-\mathrm{w}$ & ${ }^{-t}$ & n & $\mathrm{r}$ & 1 & c \\
\hline ia & 즈 & J'J & 288 & 3 & $\overline{8}$ & 26 & $r$ & \\
\hline ie & & & & 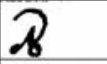 & & & & \\
\hline ii & ג ג & 正 & JOC & ९ा & $\int_{J}^{6}$ & ขy & & \\
\hline $\mathrm{i}$ & ১ & $\%$ & & $C_{0} 20$ & ep & & & $2\}^{3}$ \\
\hline ee & & 元 & ø) & 9 & $\bar{m}$ & & (ब) & गิ \\
\hline e & & \&8 & & वै। & 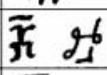 & 77 & $\mathbb{Z}^{1}$ & $\sqrt{9}$ \\
\hline$\varepsilon \varepsilon$ & 2 & $\infty_{1}$ & (ळ) & गन्न & 豆 & $\overline{\boldsymbol{\omega}}$ & & [20] \\
\hline$\varepsilon$ & $3 \mathrm{~s}$ & & & & & $y_{0}$ & $I_{0}$ & $\delta x^{2}$ \\
\hline is & $C_{2}$ & న & & S'S & $\| \mathbb{R}$ & $C_{8}$ & $: \square$ & \\
\hline ii & - क्रुक & Lे & & $\bar{r}_{1}$ & $\theta$ & $\oplus$ & & \\
\hline$i$ & .303 & เి ড্ড & & 理 & दृత⿹ & & & \\
\hline әә & 7ה & $\vec{\Delta}$ & & [ख़] & $\mathrm{D}$ & ते & & \\
\hline 。 & & $\Delta J$ & 月 & \& & 今 & & & \\
\hline$M$ & $\overline{\underline{m}}$ & 87 & & & & J & & \\
\hline$\Delta$ & & & d & & & & & \\
\hline aa & $\mathrm{eJ}$ & 厄6 & 77 & CA & G & $\mathcal{I}$ & हृ7 & \\
\hline $\mathrm{a}$ & b) & 스 구 & ชึ & 2ิ4 & 4 & H & 5 & 告 \\
\hline иа & & & & $U$ & 16 & १9 & 26 & $U y^{r}$ \\
\hline waa & & كل & & r. & & & & \\
\hline uо & & $e^{\square}$ & & & & गून & & \\
\hline uu & רד & 8 & & น & 5 & נז & गฎ & \\
\hline u & 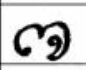 & V.] & & ब & $\vec{v} \vec{P}$ & $\widehat{\text { ss }}$ & & \\
\hline$\infty$ & vo & or & & $\mathbb{I}$ & qb & $\sqrt{5}$ & 26 & $\mathbb{I} \mathbb{R}$ \\
\hline 。 & ขิ & ขा & & $W$ & 五 & 87 & & \\
\hline כد & 6ే & วூ & 闪 & $\lambda^{0}$ & (ृ) & & & \\
\hline- & & & & re & & & & \\
\hline
\end{tabular}

Figure 1a. Syllable rhyme symbols, part 1 
Whom script 21

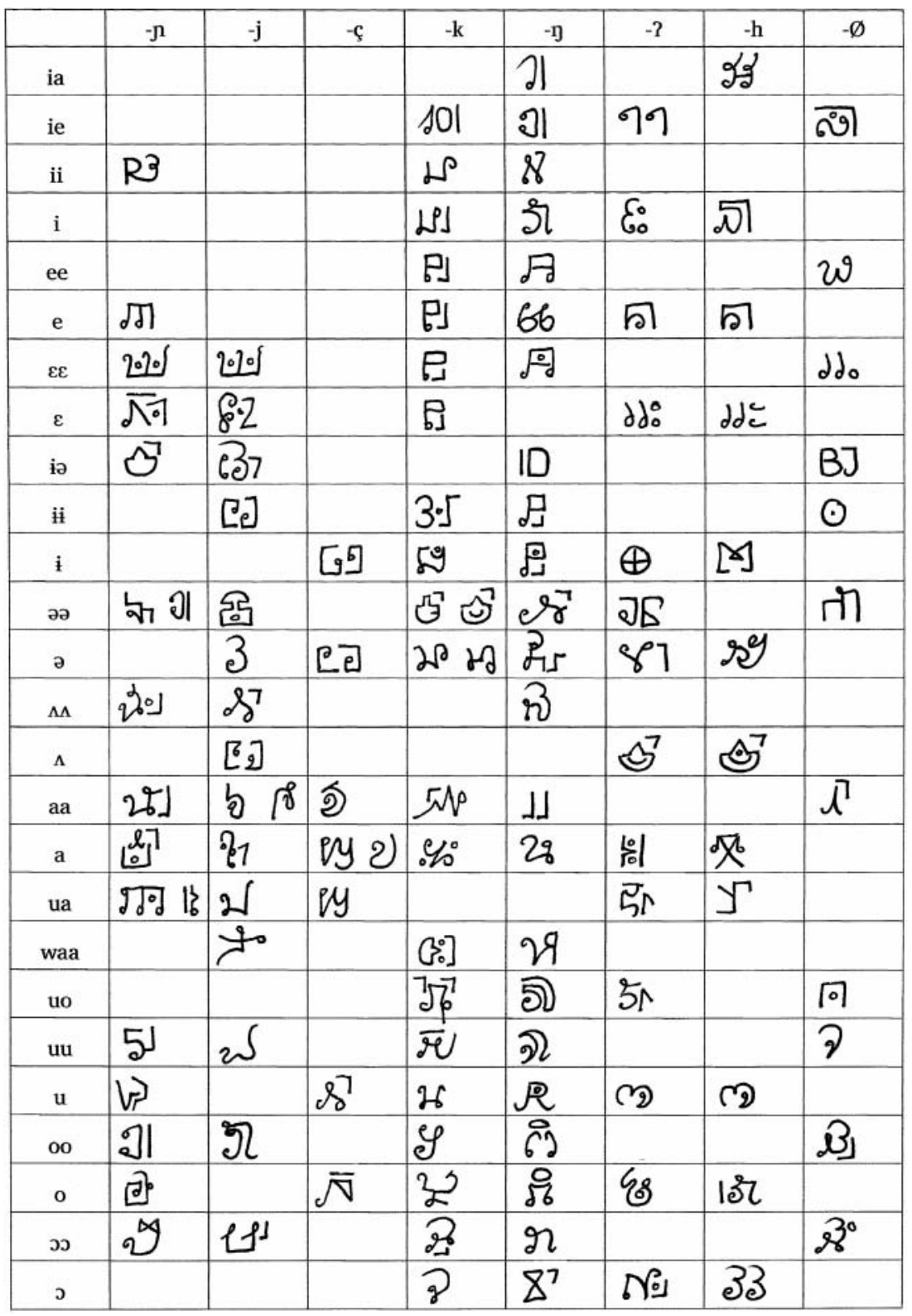

Figure lb. Syllable rhyme symbols, part 2 


\begin{tabular}{|c|c|c|c|c|c|c|c|c|}
\hline$\sigma_{k}^{\infty}$ & 3r & 88 & (2) & 8 & $\begin{array}{l}\mu b \\
\text { khl }\end{array}$ & $\omega_{\mathrm{khr}}^{5}$ & $\frac{5}{g}$ & $\underset{g r}{G}$ \\
\hline r & $\begin{array}{c}\mathcal{L} \\
\mathrm{jr}\end{array}$ & $\begin{array}{l}\text { P } \\
? \mathrm{n}\end{array}$ & & & & & & \\
\hline$\underset{c}{j}$ & 아 & $\begin{array}{c}\mathrm{R} 5 \\
\mathrm{cr}\end{array}$ & 27 & $\widehat{\omega}$ & $\underset{j}{S}$ & $\omega_{\text {ij }}$ & & \\
\hline$\omega_{n}$ & $\underset{\mathrm{nr}}{20}$ & rn & & $2 r$ & Wr & $\underset{\text { sr }}{N}$ & & \\
\hline $\mathscr{G}_{t}^{x}$ & b & को & 88 & $\mathrm{tl}$ & 28 & פ & $\bigodot_{\mathrm{dl}}$ & $\int_{d}$ \\
\hline${ }_{n}$ & $\mathcal{V P}_{\mathrm{hn}}$ & $\begin{array}{l}28 \\
\text { 2n }\end{array}$ & & & & & & \\
\hline$\biguplus_{p}$ & อ1 & $\underset{\mathrm{pr}}{\text { ने }}$ & d) & phl & गुp & 8) & को & (2) \\
\hline ค & $e_{b l}$ & $\hat{b r}$ & $\begin{array}{c}y_{1}^{6} \\
6\end{array}$ & & & & & \\
\hline $\mathcal{U}_{\mathrm{m}}$ & $\omega \mathrm{mr}^{2}$ & (Р) & \. & & & & & \\
\hline$d 2$ & $\omega$ & ق6 & $\underbrace{e y}_{2 r}$ & d & तr & $\sqrt{2}$ & $3_{h}$ & C \\
\hline
\end{tabular}

Figure 2. Syllable initial symbols

They do not otherwise like to discuss local history (it is not a society where people like to discuss matters openly with outsiders), but they are intensely proud of the fact that the Loven - and other Kha - never consented to foreign rule, in contrast to the Lao Loum, whom they contemptuously perceive as lazy and too willing to accept foreign/colonial patronage.

The exact circumstances and intentions of Kommadam in devising the script are not known. Gunn (1990: 118) relates Dauplay's report of the khabot ('rebel'): 


\begin{tabular}{|c|c|c|c|c|c|c|c|c|}
\hline & 28 & RS & S£」 & S & 26 & 5|ฮ & [9] & $2 \delta$ \\
\hline$V_{7}$ & $\llcorner 5 \mathcal{B}$ & $N P$ & עyوg & [?] & 32 & gog & भs & 订 \\
\hline & 17 & 7ે & 이마 & |م & 5 & |బ็) & תرك & o \\
\hline 京7 & 戸 & נן & L17 & है & Es & N1 & นั & ग \\
\hline 5j & $\overline{88}$ & ol & 9 & IOC & - II & bJ & $B^{\circ}$ & $x$ \\
\hline 9 & $76^{7}$ & 3 & ef' & 97 & รృ & gog & 3 & af \\
\hline דه & bJ & ห & 151 & 요 & yo & $\sqrt{\sqrt{m}}$ & 可 & 48 \\
\hline rs & च & {$[\mathbf{p}]$} & $\boldsymbol{K}$ & E 7 & X] & ३० & भil & $\triangle 1$ \\
\hline मि & 再 & $\mathbf{R}$ & $\mathcal{S}$ & $\overline{50}$ & $3 \cdot 5$ & $\mathscr{8}$ & 8] & \\
\hline $18 \%$ & $r$ & $\overline{5}$ & $\stackrel{\dot{\gamma}}{ }$ & LJ & 65 & [9] & ge & () \\
\hline $9 S^{7}$ & Zu & $\overline{\text { gog }}$ & v & หน & 69 & 295 & ?⿻弋一㇂㇒ & \\
\hline$r$ & I & भீ & d1 & 662 & $\overline{G D}$ & $\mathcal{S P}^{\circ}$ & โ91 & 4 \\
\hline तो & สู7 & 㭊 & ถิ & $\overline{\mathrm{X}}$ & $\mathscr{C}^{7}$ & $w$ & $\overline{g r}$ & \\
\hline 87 & SIJ & bl] & $B$ & r & $\pi$ & भม & \& & \\
\hline$\vec{\gamma}$ & ณิ & $\ddot{\Downarrow}$ & Q & ك & $b_{7}$ & $2 \overrightarrow{3}$ & 8) & \\
\hline$\sqrt{7}$ & $\bar{r}$ & du & 96 & 巴 & ?. & $R$ & $\nu_{1}$ & \\
\hline 107 & $\mathrm{GS}$ & SS & p & 的 & ber & Il) & कु. & \\
\hline
\end{tabular}

Figure 3. Symbols not yet identified

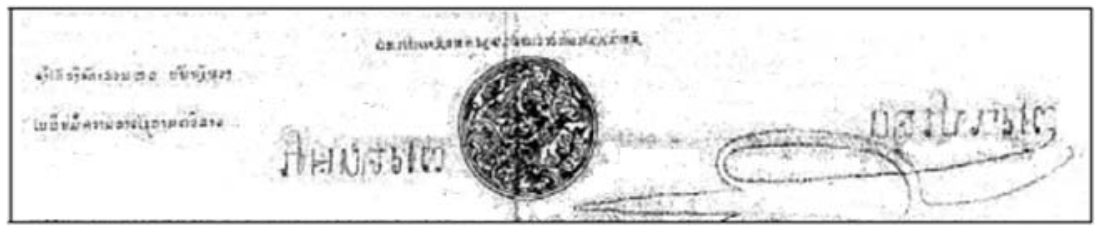

Figure 4. Seal and signatures on Kommadam's 22 February 1926 letter 
[...] indications of a resurgence of activity by the khabot was the discovery in 1924 of his "propaganda" in places as far afield as the Sekong region of Laos, the Darlac region of Vietnam and the Stung Treng region of Cambodia. This took the form of messages written in what the Kommadam called "Nang Su Khom" or Khom language script, probably intelligible to monks versed in Pali.

Connecting the Khom script to Pali is an understandable but incorrect guess. The suggestion that the script was used to circulate propaganda to disparate communities is more significant. The only way I can imagine it could have been a practical proposition is if messengers, who may or may not have been versed in reading the script, delivered the Kommadam's words verbally, bearing the otherwise incomprehensible documents as symbols of the leader's mystical powers.

Something of a parallel is seen a generation later, when in 1959 in northern Laos the Hmong messianic cult leader Shong Lue Yang devised a script for the Hmong language (see Smalley et al. 1990). ${ }^{6}$ Shong Lue's fame as the "Mother of Writing" was an important part of legitimizing his religious authority, since in the largely illiterate society of rural Laos the knowledge and teaching of writing was an activity of monks and holy men. In the case of Shong Lue's script, disciples set about disseminating and popularizing it in the hope of making a real language-planning effort. Yet in the case of Kommadam's Khom script, there is no evidence that its application ever really went beyond the inner circle of the rebellion. From what I understand from Boun Nyong's explanation, the script was taught to him as a sacred covenant, a secret to be tightly guarded, which he faithfully kept for six decades. He was to serve exclusively as Kommadam's secretary, suggesting that it was only the master's words that were to be written in it.

One may also speculate that the elaborate nature of the script is relevant. The sheer extent and complexity of the script has the effect that it can be used for any language of the area. The universality aspect was clearly symbolic of the Kommadam's claim of authority over all the Khom, while the apparently unique right to use it (by Kommadam or his immediate delegates) symbolized the exclusivity of his authority. Thus I suspect that the Khom script was perhaps never intended as a real language-planning tool, but merely a very elaborate symbol of mystical power, part of the grand religious justification of Kommadam's place at the head of the anti-colonial rebellion. 


\section{Notes}

1. The script is discussed to some extent in Pascale Jacq's (2001) M.A. thesis, which is being prepared for publication as a monograph with Mon-Khmer Studies.

2. The term Khom is from the Lao word khom, from the Mon krom 'south(erners)', originally used to designate the Khmer inhabitants of the region before the coming of the Lao, and later applied to the various Mon-Khmer peoples subsequently living under Lao domination.

3. Lao for 'slaves', these days considered a derogatory appellation.

4. The prejudice is alive and well still - highlanders who found government employment in cities with the Pathet Lao revolution often found themselves derided as Khon $\mathrm{Pa}$ 'jungle men' by the Lao Loum. A generation later, the minorities, officially still lauded as patriots, often resort to concealing their ethnic background in order to get on in society. After some time in a rural area, an outsider may be surprised to find that the inhabitants, who may have first loudly declared themselves to be Lao Loum, eventually concede that they are of other stock entirely.

5. It is not yet clear to me, but there may have been an attempt to represent Lao/Thai tones, or at least a high and low series, since it is apparent that there are some pairs of characters that otherwise have the same consonantal readings.

6. Another secret script in the area was also associated with a messianic political movement (Smalley and Wimuttikosol 1998).

\section{References}

Gunn, Geoffrey (1990). Rebellion in Laos: Peasant and Politics in a Colonial Backwater. Boulder, CO: Westview Press.

Jacq, Pascale (2001). A description of Jruq (Loven): a Mon-Khmer language of the Lao PDR. Unpublished M.A. thesis, Australian National University.

Moppert, François (1981). Le révolte des Bolovens (1901-1936). In Histoire de l'Asie du Sud-est: Révoltes, Réformes, Révolutions, Pierre Brocheux (ed.), 47-62. Lille: Presses Universitaires de Lille.

Murdoch, John (1974). The 1901-1902 "Holy Man's" rebellion. Journal of the Siam Society 62(1), 47-66.

Smalley, William; Vang, Chia Koua; and Yang, Gnia Yee (1990). Mother of Writing: The Origin and Development of a Hmong Messianic Script. Chicago: University of Chicago Press.

Smalley, William; and Wimuttikosol, Nina (1998). Another Hmong messianic script and its texts. Written Language and Literacy 1, 103-128. 